\title{
Evaluation and Analysis of Soil Stabilization with Some Non- Conventional Additives
}

\author{
Poonam Tripathi ${ }^{1}$, D.S. Ray ${ }^{2}$ \\ ${ }^{1}$ M. Tech. Scholar, Department of Civil Engineering, BBDU, Lucknow, India \\ ${ }^{2}$ Prof. and Head of Department of Civil Engineering, BBDNITM, Lucknow, India.
}

\begin{abstract}
The growth of population has created a need for better and economical vehicular operation which requires good highways, proper geometric design and pavement condition maintenance. Road transportation is undoubtedly the lifeline of the nation and its development is crucial concern. The process of soil stabilization helps to achieve the required properties in a soil needed for the pavement construction work. One of the main reason for the failure of pavement is due to lack of strength. Strength can be increased by adding additive materials to the sub-grade in different proportions. The work presented in this paper deals with the strength properties of natural and stabilized subgrade. In this research, Silica fume, Recron 3-S fibre and Terrasil are used as stabilizers in improving engineering properties of soil. The aim of this study is to evaluates the effect of different percentages of Silica fume, Recron 3-S fibre and Terrasil are used separately and combination as stabilizers to improve the sub-grade characteristics of locally available soil. Mainly we have focused on increasing the CBR of the soil because on increasing the CBR value it helps in reducing the thickness of the pavement and it is also beneficial to use economically.
\end{abstract}

Keywords:- Soil, Silica fume (SF), Recron 3-S fibre (RF), Terrasil (T), Stabilization, Strength parameters, CBR Test.

\section{INTRODUCTION}

Due to rapid growth of population, very high utilization of land reserves, fast utilization and some other major civil engineering constructions, availability of good quality of land has been reduced which left less choice to people except to use weak and soft soil surrounding for majority of construction works.

In India, the modern era of soil stabilization began in early 1970 's, with a general shortage of petroleum and aggregates, it become necessary for the engineers to look at means to improve soil other than replacing the poor soil at building site. Soil stabilization was used but due to the use of obsolete methods and due to the absence of proper technique, soil stabilization lost favour.

In recent times, with the increase in the demand for infrastructure, raw materials and fuel, soil stabilization has started to take a new shape. With the availability of better research, materials and equipment, it is emerging as a popular and cost effective method for soil improvement. One of the common approaches of subgrade stabilization is to remove the soft and replace it with a stronger material of crushed rock. The high cost of replacing has found forced highway agencies to evaluate alternative method for highway construction on soft subgrade. Pavement performance can be largely attributed to the performance of its foundation, which comprises of the subgrade and base layers. Base and subgrade layers must provide enough shear strength, stiffness modulus, resistance to moisture, stability and durability.

In country like India which is rich in monsoons, moisture becomes a huge problem to roads. Admission of water in rainy season weakens the road soil base. The soil of poor shear strength and high swelling and shrinkage, must be treated by some suitable means mostly soil stabilization and reinforcement are employed to improve mechanical behaviour of soil, thus improving the reliability of construction.

Road Infrastructure plays a significance role in the country's economy by providing efficient and cheapest transport facilities in both developed and developing countries. Pavement is the one of primary element and important component in the road infrastructure, which provides firm surface for smooth, safe and efficient movement of vehicular traffic. Subgrade is the integral part of the pavement system, which plays a major role in providing sound durable surface. Subgrade is defined as a compacted layer naturally occurring local soil or stabilized soil from borrow pits just beneath the pavement crust, providing a suitable foundation for the pavement structure. Subgrade layer should be well compacted at all situations to utilize its full strength to economize on the overall pavement thickness. Subgrade layer play an important role in imparting structural stability to the pavement structure as it receives dynamic transient loads imposed upon it by vehicular traffic. These Traffic loads need to be transmitted in a systematic manner in such a way that the subgrade deformation is to be within the elastic limits, and the shear forces developed are to be within the safe limits under adverse climatic and traffic loading conditions.

In case of highways less CBR value soils require higher pavement thickness of design traffic, resulting in costly pavement composition. To overcome this problem associated with soil, many techniques have been developed by different researches in terms of subgrade stabilization.

\subsection{SOIL STABILIZATION}

Stabilization of soil in a broader sense is the modification of the properties of a soil is improving its engineering performance. Soil stabilization is broadly used about road, pavement and foundation construction. It improves the engineering properties of the soil in terms of volume stability, strength and durability.

In case of road construction, the aim of stabilization of soil to increase the stability by increasing its bearing capacity and hence increasing its strength and reduction in pavement thickness. Soil stabilization improves the strength of the soil, 
thus, increasing the soil bearing capacity, used to decrease permeability and compressibility of the soil mass in the earth structure, more economical both in terms of cost and energy to increase the bearing capacity of soil, improves workability and durability of the soil and maximize the lifecycle costs of projects.

\subsection{EFFECTS OF STABILIZATION}

Soil stabilization may result in any one or more of the following changes:

1) Increase in stability, change in properties like density or swelling, change in physical characteristics.

2) Change in chemical properties.

3) Retaining and desired strength by water proofing.

\section{LITERATURE REVIEW}

The following literature review describes important research results regarding use of Silica fume, Recron-3S fibre and Terrasil in soil improvement:

Nandan A. Patel, C. B. Mishra (2015) ${ }^{13}$ studied on Subgrade Soil Stabilization using Chemical Additives". It is found that the addition of Terrasil $(0.041 \%)+$ zycobond $(0.020 \%)$ to the soil the CBR value increased from $6.64 \%$ to $12.15 \%$. This signifies that the quality of subgrade soil is enhanced consequently expanding the load carrying limit of pavement.

Rintu Johnson1, Dr. Kodi Rangaswamy (2015) ${ }^{\mathbf{1 5}}$ The soil was collected from Kunnamangalam area of Calicut district in Kerala and the Terrasil Nano-chemical was collected from Zydex, Industries Ltd. for the stabilization studies. Experimental programme was carried out on both clay and cement treated clay treated with different dosages of Terrasil. Specimens were prepared with $0.05 \%, 0.07 \%$ and $0.09 \%$ Terrasil and $1 \%$ cement by weight of soil. Results obtained were compared and studied. The CBR strength of soil mixed with optimum dosage of $0.07 \%$ terrasil chemical is improved about 6 times the CBR strength of clay soil. The treated soil was found to be impermeable.

A.R.Goodarzia, H.R.Akbaria (2016) ${ }^{\mathbf{3}}$ The present study investigated the potential use and effectiveness of expansive clay stabilization using admixture of cement and silica fume (CSF) as a possibly useful option from environmental, economic, and (or) technical perspectives. In so doing, cement and CSF blend with $10 \%$ cement replacement were separately added to a clay sample having high degree of swelling potential. The incorporation of silica fume in to the cement matrix extends the formation of new cementing compounds and provides a much denser. micro structure, were found to be very effective in surpassing the problems associated with expansive clays. Adding 10\% CSF within 14 days of curing increases the compressive strength of the clay.

Kolla Ashwani Chandh et al (2016) ${ }^{12}$ studied on the Effect of Fibre on Non-Swelling Sub Grade Layer. In this study, Recron 3 s fibre is mixed with soil to investigate the relative strength gain in terms of bearing capacity and compaction.
The effect of fibre on the geotechnical characteristics of soilfibre mixture was investigated by conducting standard Proctor compaction tests, CBR tests and permeability test. The tests were performed as per Indian Standard specifications. The materials were used for preparing the samples are Soil \& Fibre. The soil used for these experiments was brought from a site, in our college. The physical properties of the soil were determined as per IS specifications. In this test program, without additives clay was tested to find the optimum moisture content, $\mathrm{CBR}$ value and plasticity index. Fibre is added in varying percentages and that fraction for which maximum strength is obtained was found out. These experiments resulted in decreasing the subgrade thickness to $50 \%$ of the actual thickness required, thereby reducing the cost of construction.

Ansu Thomas, R. k. Tripathi (2016) ${ }^{1}$ In this study, an attempt has been made to study the improvement in the properties of a soft soil collected from village Arasnara, Durg district of Chhattisgarh, India, stabilized with Terrasil. Various laboratory tests have been conducted on unstabilized and stabilized soil samples and the results are compared and discussed. Different dosages of Terrasil have been used and evaluated the effect on optimum moisture content, maximum dry density, plasticity index and Unconfined Compressive Strength (UCS). Effect of curing period on UCS has also been studied. Significant improvement in properties of soil is observed.

P. Sai Venkata Bharath1, K. Jyothi Raju (2016) ${ }^{14}$ This paper includes the evaluation of soil properties like compaction and California Bearing Ratio (CBR) test. Detailed experimental study has been undertaken to investigate the characteristics and behaviour of expansive soil mixed with Quarry Dust and Recron-3S fibres with different percentage. From the experimental results, it has been observed that various properties of soil added with these stabilizers at certain percentage show remarkable positive changes as compared to the natural soil. The value of compaction parameters has increased enabling increase California Bearing Ratio which indicates that improved in strength.

Siyyagalla Subbarayudu, S. Rozwana $(2017){ }^{16}$ In this project, we are going to stabilize the soil by using recron-3s, fly-ash and lime. Here we are using recron-3S as $(1 \%, 2 \%$, lime $(2 \%, 3 \%, 4 \%)$ and fly ash at $(10 \%, 12 \%, 15 \%, 20 \%)$. With different proportion of soil with additive materials California bearing ratio value will be more compare to conventional materials. And from that thickness of pavement can be minimized to a certain extent.

\section{MATERIALS}

The materials used for the stabilization of soil are Silica fume, Recron fibre and Terrasil and the properties and availability are mentioned below:

3.1 SOIL: The soil sample used for this study is collected from Krishna Nagar, Lucknow. 
Table 1: Properties of Soil

\begin{tabular}{|l|l|}
\hline Properties & Description \\
\hline Liquid limit (\%) & 30 \\
\hline Plastic limit (\%) & 21 \\
\hline Plasticity Index (\%) & 9 \\
\hline Soil Classification & CI \\
\hline Optimum moisture content (\%) & 14 \\
\hline Maximum dry density (gm/cc) & 1.84 \\
\hline Soaked CBR (\%) & 5.03 \\
\hline
\end{tabular}

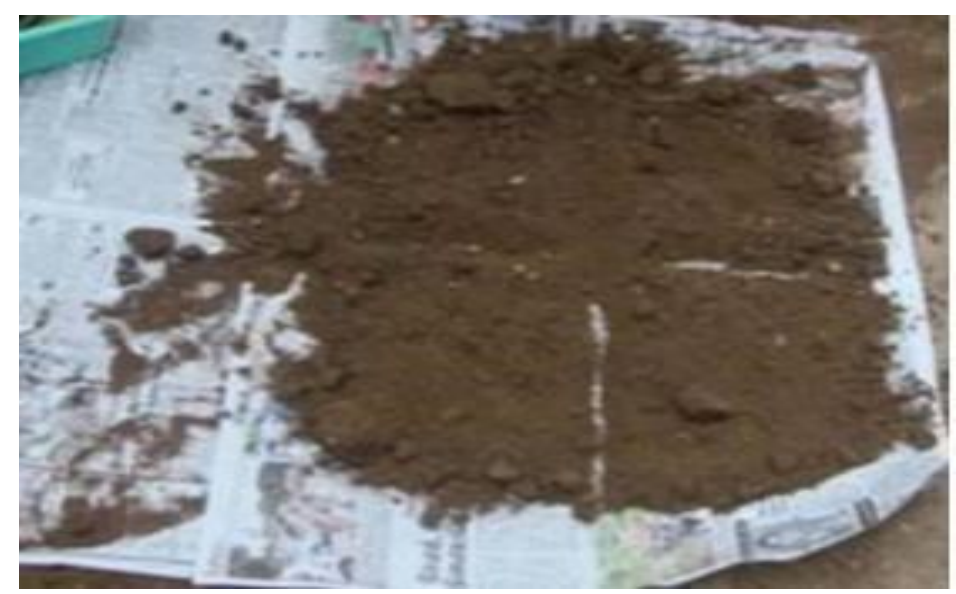

Fig. 1: Soil Sample

3.2 SILICA FUME: Silica fume, also known as Micro Silica, is an ultrafine powder collected as a by-product of silicon metal. It is a pozzolonic material which has a high content of amorphous silicon dioxide and consists of very fine spherical particles. It is available in grey to off-white colours. The particles of SF are 100 to150 times smaller than the cement grains. It is one of the most valuable by-product pozzolonic materials due to its very active and high pozzolonic property. Micro silica fume improves compressive strength, bond strength and reduce permeability.

Table 2: Physical Properties of Silica fume

\begin{tabular}{|l|l|}
\hline Properties & Description \\
\hline Colour & Light to dark grey \\
\hline Specific gravity & 2.2 \\
\hline Particle size & $<1 \mathrm{~m} \mu$ \\
\hline Specific surface & $15000-30000 \mathrm{~m} 2 / \mathrm{kg}$ \\
\hline Bulk density & \\
-Undensified & $130-430 \mathrm{~kg} / \mathrm{m} 3$ \\
-Densified & $480-720 \mathrm{~kg} / \mathrm{m} 3$ \\
\hline
\end{tabular}

Table 3: Chemical Composition of Silica fume

\begin{tabular}{|l|l|}
\hline Compound & Value $(\%)$ \\
\hline $\mathrm{SiO}_{2}$ & $85-95$ \\
\hline $\mathrm{Al}_{2} \mathrm{O} 3$ & $1-3$ \\
\hline $\mathrm{Fe}_{2} \mathrm{O} 3$ & $0.5-1$ \\
\hline $\mathrm{CaO}$ & $0.8-1.2$ \\
\hline $\mathrm{MgO}$ & $1-2$ \\
\hline Loss on Ignition & $0.5-1$ \\
\hline
\end{tabular}




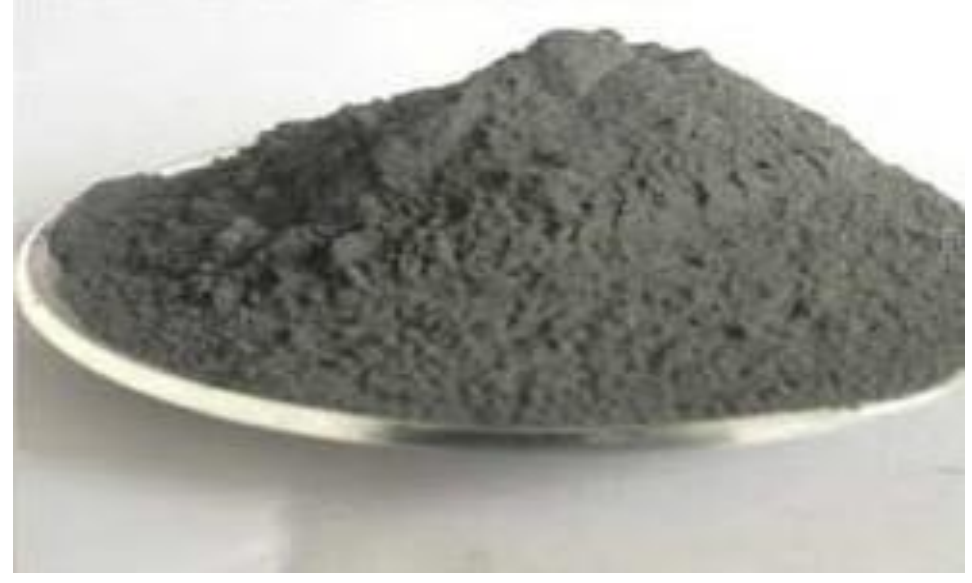

Fig 2: Silica fume

3.3 RECRON 3-S FIBRE: Recron-3S is most commonly used synthetic fibre due to its low cost, hydrophobic nature, chemically inert and does not allow reaction with soil moisture. Use of Recron-3S as a reinforcing material is to increase the performance in terms of strength of soil also it enhances flexibility in operation, easy to use and reduces permeability. Recron-3s is also available in different sizes as $6 \mathrm{~mm}, 12 \mathrm{~mm}$ and $24 \mathrm{~mm}$. The fibre used in this study of length $12 \mathrm{~mm}$ and it was manufacture by Reliance industries.

Table 4: Properties of Recron 3-S fibre

\begin{tabular}{|l|l|}
\hline Properties & Description \\
\hline Colour & White \\
\hline Length & $12 \mathrm{~mm}$ \\
\hline Unit length & $0.91 \mathrm{~g} / \mathrm{cm}^{3}$ \\
\hline Tensile strength & $4000-6000 \mathrm{~kg} / \mathrm{cm}^{2}$ \\
\hline Water absorption & $85.22 \%$ \\
\hline Acid resistance & Excellent \\
\hline Alkali resistance & Good \\
\hline
\end{tabular}

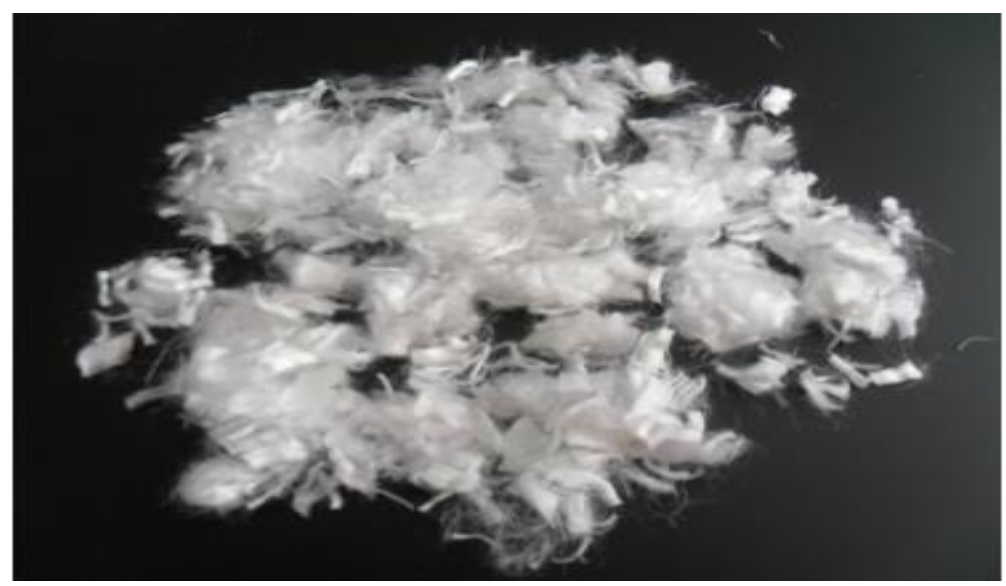

Fig 3: Recron 3-S Fibre

3.4 TERRASIL: Terrasil chemical is emerging as a new material for the stabilization of soil. Terrasil is nanotechnology based product produced by Zydex Industries Ltd., Gujarat. It is defined as an organo-silane compound which reacts with soil particles and converts them (all types of soils) from water loving (Hydrophilic polar) to water hating (Hydrophobic nonpolar) particles. This makes the soil insensitive to water and can be compacted to give better interlocking to the soil particles.

Table 5: Physical properties of Terrasil.

\begin{tabular}{|l|l|}
\hline Properties & Description \\
\hline Appearance & Pale yellow liquid \\
\hline Density & $1.01 \mathrm{~g} / \mathrm{ml}$ \\
\hline Viscosity at $25^{\circ} \mathrm{C}$ & $20-100 \mathrm{Cp}$ \\
\hline Solubility & Forms water clear solution \\
\hline Flash Point & $>80^{\circ} \mathrm{C}$ \\
\hline Freezing Point & $5^{\circ} \mathrm{C}$ \\
\hline
\end{tabular}


Table 6: Chemical composition of Terrasil

\begin{tabular}{|l|l|}
\hline Chemical compound & Value $(\boldsymbol{\%})$ \\
\hline Hydroxyalkyl-Alkoxy-Alkyls & $65-70$ \\
\hline Benzyl alcohol & $25-27$ \\
\hline Ethylene glycol & $3-5$ \\
\hline
\end{tabular}

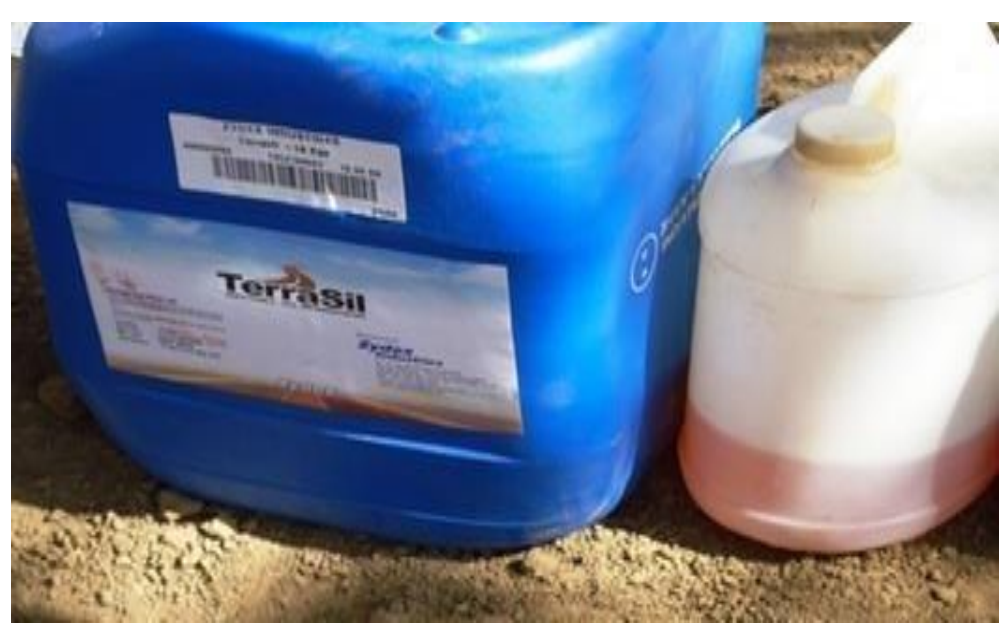

Fig 4: Terrasil

\section{METHODOLOGY}

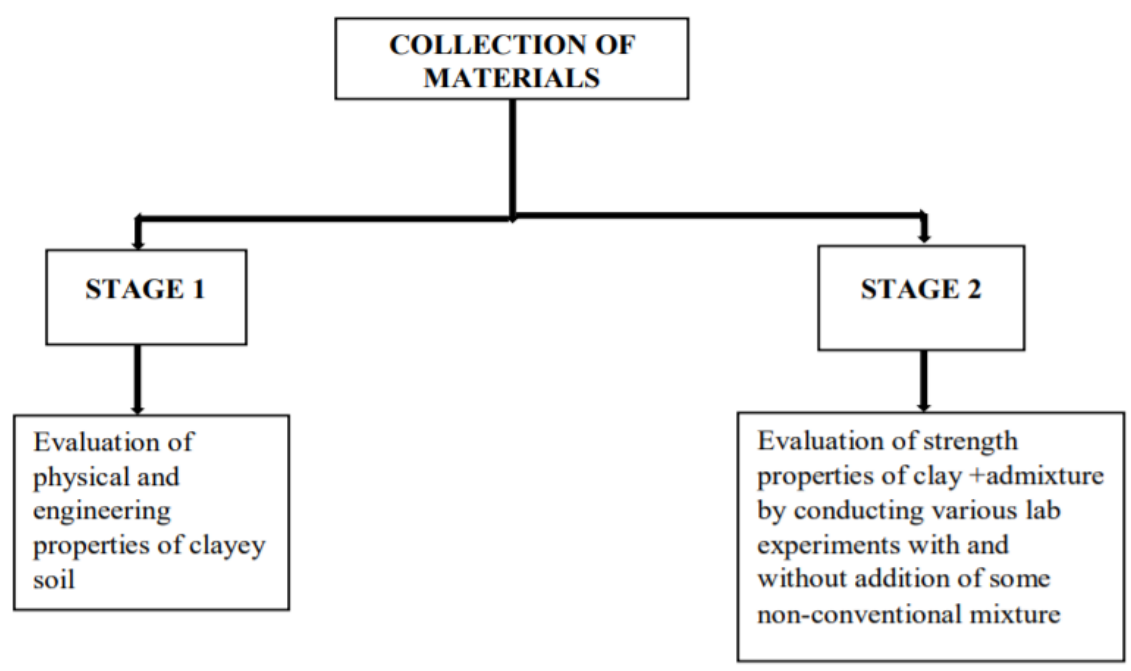

The common tests that are performed by various researcher on use of Silica fume, Recron $3 \mathrm{~S}$ fibre and Terrasil to improve soil by adding in different percentages includes following laboratory tests:

- Grain size distribution

- Liquid Limit

- Plastic Limit

- Standard Proctor Test

- California Bearing Ratio Test

\section{EXPERIMENTAL INVESTIGATION}

The overall testing program is conducted in two phase.

In first phase, soil was blending with various percentages of silica fume, Recron $3 \mathrm{~S}$ fibre and Terrasil by weight were used for conducting various tests in laboratory with a view to determine the optimum percentage of SF, RF and Terrasil. The optimum percentage of SF, RF and Terrasil content is obtained from the results of compaction and soaked CBR tests.

In second phase, soil was blending with optimum percentage of SF, RF and Terrasil by weight were used for preparing different samples for compacting and soaked CBR test.

Different samples were prepared for CBR test using soil material mixing with different percentages of Silica fume, Recron-3S Fibre and Terrasil with a view to determine optimum percentages. The CBR tests were conducted in the laboratory for all the samples as per IS Code (IS: 2720 (Part16)-1979) under soaked condition.

Perform the test with combination of optimum dosages of stabilizing agent which show maximum value of CBR. 
5.1 STABILIZER: SILICA FUME+RECRON 3-S FIBRE

Table 7: CBR test results of $\mathrm{SF}+\mathrm{RF}$

\begin{tabular}{|c|l|c|}
\hline S.No. & Stabilizer & CBR Value (\%) \\
\hline 1 & Soil & 5.03 \\
\hline 2 & Soil+Silica fume(15\%)+Recron 3-S fibre(2\%) & 13.1 \\
\hline
\end{tabular}

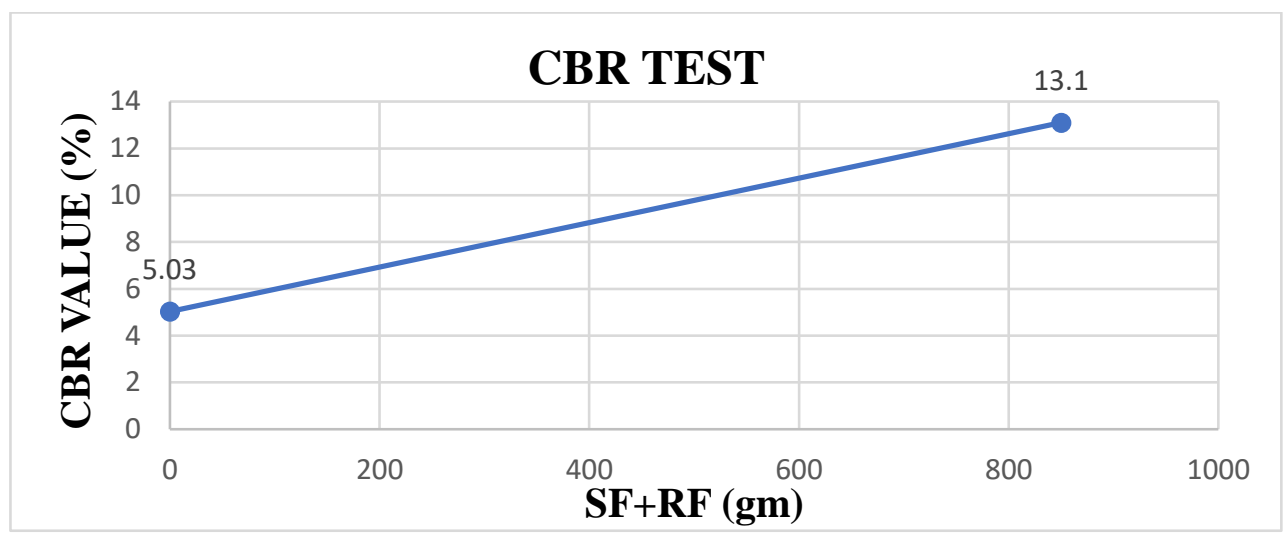

Graph 1: CBR value after adding $\mathrm{SF}+\mathrm{RF}$

5.2 STABILIZER: SILICA FUME+ TERRASIL

Table 8: CBR test results of $\mathrm{SF}+\mathrm{T}$

\begin{tabular}{|c|c|c|}
\hline S.No. & Stabilizer & CBR Value (\%) \\
\hline 1 & Soil & 5.03 \\
\hline 2 & Soil+ Silica fume $(15 \%)+$ Terrasil $\left(1.5 \mathrm{~kg} / \mathrm{m}^{3}\right)$ & 13.5 \\
\hline
\end{tabular}

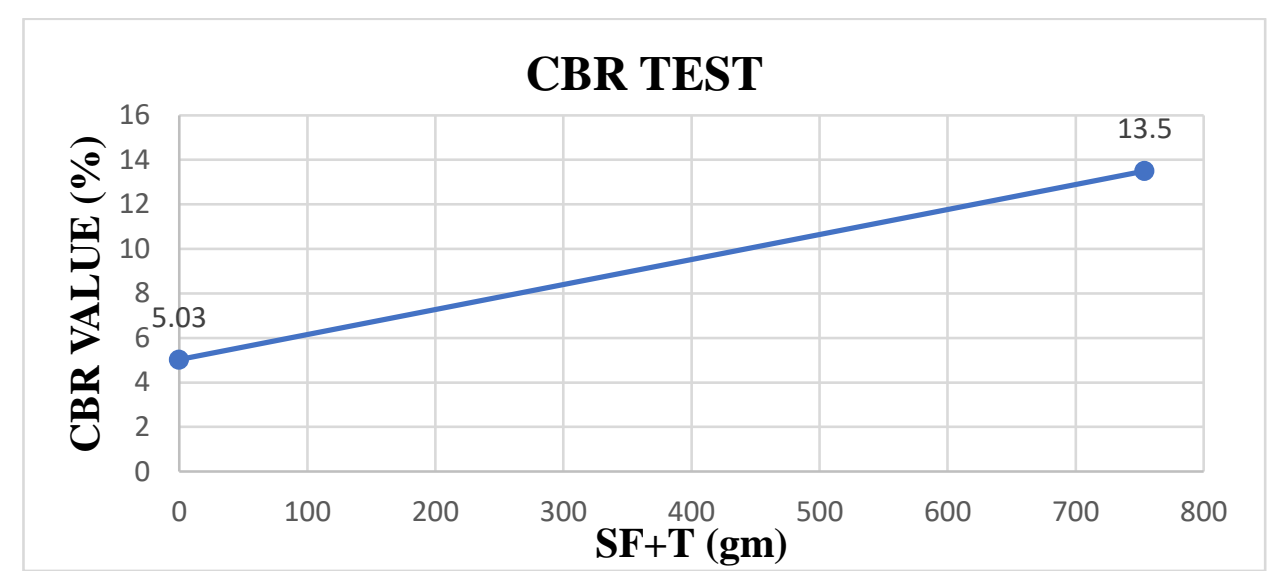

Graph 2: CBR value after adding $\mathrm{SF}+\mathrm{T}$

\subsection{STABILIZER: SILICA FUME +RECRON 3-S FIBRE + TERRASIL}

Table 9: CBR test results of $\mathrm{SF}+\mathrm{RF}+\mathrm{T}$

\begin{tabular}{|l|l|l|}
\hline S.No. & Stabilizer & CBR Value (\%) \\
\hline 1 & Soil & 5.03 \\
\hline 2 & Soil+ Silica fume $(15 \%)+$ Recron3Sfibre $(2 \%)+$ Terrasil $\left(1.5 \mathrm{~kg} / \mathrm{m}^{3}\right)$ & 14.5 \\
\hline
\end{tabular}




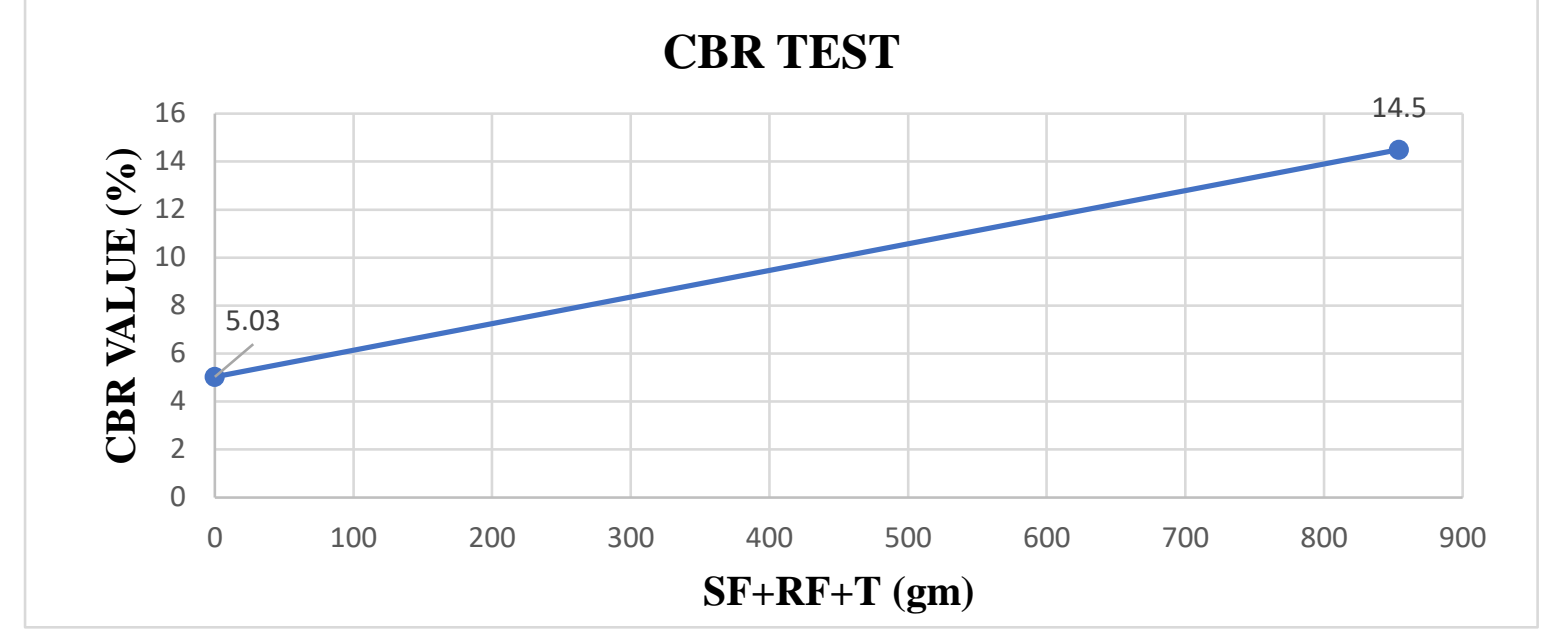

Graph 3: CBR value after adding $\mathrm{SF}+\mathrm{RF}+\mathrm{T}$

\section{TEST RESULTS AND DISCUSSION}

Based on the CBR values obtained the overall crust thickness of the pavement has been calculated. It is seen that required thickness are considerably reduced. Finally, extra cost must be compared with respect to non-admixture CBR value.

Stabilized subgrade with higher CBR value reduces the pavement thickness. The thickness of crust varies with the change in the value of CBR, below Shown are the crust thickness with different percentages of CBR:

Table 10: REDUCTION IN PAVEMENT THICKNESS WITH STABILIZED SUBGRADE

\begin{tabular}{|c|c|c|c|c|c|c|c|}
\hline \multirow{4}{*}{ S.No } & \multirow{4}{*}{ Admixture } & \multirow{4}{*}{$\begin{array}{l}\text { CBR } \\
\text { value }\end{array}$} & \multicolumn{4}{|c|}{ Crust Thickness } & \multirow[b]{3}{*}{ Surface course } \\
\hline & & & \multirow{3}{*}{$\begin{array}{l}\text { Total crust in } \\
\text { mm }\end{array}$} & \multicolumn{3}{|c|}{ Crust Composition } & \\
\hline & & & & $\begin{array}{l}\text { Sub } \\
\text { base }\end{array}$ & $\begin{array}{c}\text { Base } \\
\text { bituminous }\end{array}$ & $\begin{array}{c}\text { Base } \\
\text { bituminous }\end{array}$ & \\
\hline & & & & $\begin{array}{l}\text { GSB } \\
\text { in mm }\end{array}$ & WMM in $\mathbf{m m}$ & DBM in $\mathbf{m m}$ & $\mathrm{BC}$ in $\mathrm{mm}$ \\
\hline 1 & Non- Admixture & 5.03 & 600 & 200 & 250 & 110 & 40 \\
\hline 2 & Silica fume & 12.5 & 540 & 200 & 250 & 50 & 40 \\
\hline 3 & $\begin{array}{l}\text { Recron-3S } \\
\text { Fibre } \\
\end{array}$ & 9.4 & 560 & 200 & 250 & 70 & 40 \\
\hline 4 & Terrasil & 9.9 & 560 & 200 & 250 & 70 & 40 \\
\hline 5 & SF+RF & 13.1 & 540 & 200 & 250 & 50 & 40 \\
\hline 6 & $\mathrm{SF}+\mathrm{T}$ & 13.5 & 540 & 200 & 250 & 50 & 40 \\
\hline 7 & $\mathrm{SF}+\mathrm{RF}+\mathrm{T}$ & 14.5 & 530 & 200 & 250 & 50 & 30 \\
\hline
\end{tabular}

Table 11: COST SAVING IN CONSTRUCTION WITH RESPECT TO NON- ADMIXTURE SUB GRADE SOIL

\begin{tabular}{|c|c|c|c|c|c|c|c|c|}
\hline \multicolumn{9}{|c|}{ COST ANALYSIS PER KM } \\
\hline S.No. & Admixture & $\begin{array}{l}\text { Qty. of } \\
\text { DBM }\end{array}$ & $\begin{array}{l}\text { RATE } \\
\text { per cum }\end{array}$ & $\begin{array}{l}\text { Qty. of } \\
\text { BC }\end{array}$ & $\begin{array}{r}\text { RATE } \\
\text { per cum }\end{array}$ & $\begin{array}{c}\text { Amount } \\
(\mathrm{DBM}+\mathbf{B C})\end{array}$ & $\begin{array}{l}\text { Amount in } \\
\text { lacs. }\end{array}$ & $\begin{array}{l}\text { Net } \\
\text { Saving } \\
\text { in lacs. }\end{array}$ \\
\hline 1 & Non- Admixture & 770 & 8805.27 & 280 & 9664.85 & 9486216 & 94.86 & - \\
\hline 2 & \begin{tabular}{|l} 
Silica \\
Fume
\end{tabular} & 350 & 8805.27 & 280 & 9664.85 & 5788003 & 57.88 & 36.98 \\
\hline 3 & $\begin{array}{l}\text { Recron 3S } \\
\text { Fibre }\end{array}$ & 490 & 8805.27 & 280 & 9664.85 & 7020740 & 70.21 & 24.65 \\
\hline 4 & Terrasil & 490 & 8805.27 & 280 & 9664.85 & 7020740 & 70.21 & 24.65 \\
\hline 5 & SF+RF & 350 & 8805.27 & 280 & 9664.85 & 5788003 & 57.88 & 36.98 \\
\hline 6 & SF+T & 350 & 8805.27 & 280 & 9664.85 & 5788003 & 57.88 & 36.98 \\
\hline 7 & $\mathrm{SF}+\mathrm{RF}+\mathrm{T}$ & 350 & 8805.27 & 210 & 9664.85 & 5111463 & 51.11 & 43.75 \\
\hline
\end{tabular}


After analyzing all the data that is collected or generated, it is found that is $(\mathrm{SF}+\mathrm{RF}+\mathrm{T})$ the best combination of admixture for soil stabilization and most economical as compared to the individual admixtures used for soil stabilization.

\section{CONCLUSION}

A very important parameter, CBR (California Bearing Ratio) is used as tool for determining the improvement of strength of soil in Highway Construction. CBR determined with the help of CBR apparatus by adding admixtures (Silica fume, Recron fibre and Terrasil) with various percentages. The Total work is comprised with Zero percentage of admixture in same quality of soil. Each type of admixture with variable percentages show different trend of CBR values.

The following conclusion have been drawn based on the laboratory investigation carried out in this study:

- It has been observed that CBR value of parent soil increased with the increasing in addition of Silica fume, Recron fibre and Terrasil.

- It has been observed that Silica fume can tremendously increase the CBR value of local soil more proficiently at $15 \%$ as compared to Recron fibre and Terrasil.

- As per data available:

It has been observed that when admixtures added to the soil in individually and combination of two admixtures, crust thickness is not more less in comparison to combination of these three $(\mathrm{SF}+\mathrm{RF}+\mathrm{T})$ three admixtures.

When the combination of admixture $(\mathrm{SF}+\mathrm{RF}+\mathrm{T})$ is added in soil crust thickness is reduced more as compared to non-admixture soil.

The cost of non-admixture soil is 94.86 lacs. and the cost of combination of these three admixtures $(\mathrm{SF}+\mathrm{RF}+\mathrm{T})$ is 51.11 lacs. Thus, net saving is 43.75lacs.i.e. huge amount of money is saved here. Which is satisfying the objective of my thesis.

- After analysing all the data that is collected or generated, it is found that is $(\mathrm{SF}+\mathrm{RF}+\mathrm{T})$ the best combination of admixture for soil stabilization and most economical as compared to the individual admixtures used for soil stabilization.

- The thickness of crust varies with the change in the value of $\mathrm{CBR}$ with higher value of $\mathrm{CBR}$ the crust thickness is less and vice -versa.

- Due to the saving in crust less quantity of material will be applicable so that, huge amount of money can be saved.

\section{FUTURE SCOPE}

Based on present findings, it is felt that further work should be pursued in the following area:

- Further investigation could be done with other admixtures with different percentages, individual and combinations.

- For advance research, it is recommended that the effect of combining the three additives (Silica fume, Recron fibre and Terrasil) in the stabilization of locally available soil be investigated to see whether it can better improve the properties of soil than by using an additive alone.
- Future research may be done in this direction to know the exact cause and remedial measures against the low capacity of soil in improving soil subgrade strength.

- Future study should investigate the other stabilizing materials and their respective strength parameters correlation for soaked and unoaked CBR should be checked.

\section{REFERENCES}

[1] Ansu Thomas, R.K. Tripathi, "Soil Stabilisation Using Terrasil". International Journal of earth sciences and engineering", e -ISSN 0974-5904, Volume 09, No. 03, June 2016.

[2] AASHTO (1986): "Standard Specification for Transportation Materials and Methods of Sampling and Testing ", 14th Edition. Am. Assoc. of State Hwy. and Transp. Officials, Washington, D.C.

[3] A.R. Goodarzi a,H.R. Akbaria (2016), "Enhanced stabilization of highly expansive clays by mixing cement and silica fume". Applied Clay Science 132- 133(August,2016) 675-684.

[4] Ekrem Kalkan (2008), "Influence of silica fume on the desiccation cracks of compacted clayey soils”. Applied Clay Science 43,296302 .

[5] IS: 2720 (Part II) - 1973, Determination of Water Content.

[6] IS: 2720 (Part IV) - 1985, Determination of Grain Size Analysis.

[7] IS: 2720 (Part V) - 1985, Determination of Liquid and Plastic Limit.

[8] IS: 2720 (Part VIII) - 1987, Determination of Water Content - Dry Density Relation Using Light Compaction.

[9] IS 2720(Part 10, 1991) Unconfined Compressive Strength

[10] IS: 2720 (Part XVI) - 1997, Laboratory Determination of CBR.

[11] IRC:37-2018, Design of flexible pavement.

[12] Kolla Aswani Chandh, "A Study on Effect of Fibre on Non-Swelling Sub GradeLayer, International Journal of Engineering Science and Computing”, September 2016, Volume 6 Issue No. 9.

[13] Nandan A. Patel, C. B. Mishra, D. K. Parmar, Saurabh B. Gautam (2015) "Subgrade Soil Stabilization using Chemical Additives". International Research Journal of Engineering and Technology (IRJET) e-ISSN: 2395-0056 Volume: 02 Issue: 04 | July- 2015

[14] P. Sai Venkata Bharath, K. Jyothi Raju (2016), "Performance of Recron-3S Fiber with Quarry Dust in Expansive Soil Stabilization". International Journal of Science and Research (IJSR) ISSN: 23197064.

[15] Rintu Johnson, Dr. Kodi Rangaswamy (2015), "Improvement of soil properties as a road base material using nano chemical solution", Indian geotechnical society (estd. 1854), December 2015.

[16] Siyyagalla Subbarayudu, S.Rozwana (2017), "Study of soil stabilization by using recron-3s, fly-ash \& lime". International Journal for Technological Research in Engineering Volume 4, Issue: 9. 